\title{
Editorial
}

\section{Teaching as a research-engaged profession: Uncovering a blind spot and revealing new possibilities}

\section{David Lambert* - UCL Institute of Education, UK}

Anyone running their eyes down the contents list of this London Review of Education special feature on knowledge and subject-specialist teaching will quickly get the idea that the three recurring keywords are teaching, knowledge and curriculum. These words capture a good deal of what schools are for. They are, in a sense, defining categories, for whatever the multiplicity of roles and functions that are thrust onto schools, what remains at the core is knowledge - and teachers who interpret and enact the official curriculum. 'After all,' as Michael Young (2018) writes, 'what else could schools be for if it were not to provide access to knowledge that children would not have if they were forced to rely, as most were prior to the nineteenth century, on their families, communities and workplaces.' This is not to convey a 'deficit' view of those children, nor of the families, communities and workplaces from which they came. Teachers can - perhaps, must - show an unconditional positive regard for the children they teach. Indeed, as David Hopkins stresses 'a key characteristic of outstanding teachers [is] their love of children' (1996: 98). And yet this, clearly, is not enough. Arguably the most profound demonstration of respect that teachers can show for children is their 'moral purpose' (Fullan, 1993: 10), which includes clarity over the value of what they are trying to teach to whoever they are teaching.

Knowledge itself, therefore, is of central concern. Even so, a focus on knowledge alone can easily lead to a kind of navel-gazing that is centred on challenging philosophical debates about the meaning of knowledge (for example, see White, 2018). These risk stalling progress on broader questions, such as how can teachers make specialist, often abstract, knowledge available in a way that motivates and engages the interest of all students - as a 'pedagogic right', to paraphrase Basil Bernstein (2000) - so as to enable new and powerful ways to understand the world and how it works. We therefore need to think hard about the implications of what Young means by schools needing to 'provide access to knowledge', for one thing we have learned from the late Geoff Whitty's work (1985) is that it is not simply a case of treating all children equally. Pupils from different circumstances and with different life experiences need different approaches if they are to engage successfully with knowledge. Schools are institutions which, depending on their organization and leadership (and a whole lot more besides), may be of very limited agency in this regard. A crucial focus must be on the teachers and their agency to enact a curriculum that achieves far more than providing 'access' in a take-it or leave-it kind of way (with an unspoken assumption that some, or even many, children may simply reject the offer). Teachers, of course, need to be very interested in their students and not take for granted their willingness to engage with knowledge 
which, to use the neo-Marxist language of the new sociology of education from the 1970s, they may find 'alienating'.

But as Gert Biesta (2017) reminds us repeatedly, taking an ill-balanced interest in students-as-learners in a manner that sidelines knowledge can distort the educational encounter into one that undermines the purpose of schoolteaching through a process of 'learnification'. Through this process, subject specialism is undermined and, especially for low-attaining children or those from more deprived socio-economic circumstances, alternative 'less academic' curriculum arrangements are often devised. According to the recent GeoCapabilities project ${ }^{1}$, this risks a particular form of capabilities deprivation (Uhlenwinkel et al., 2017) for those pupils deemed unsuited for the highstatus knowledge reserved for the high achievers. If teachers are primarily knowledge workers who are - and should be - driven by questions of why their subject teaching matters and what their students are making of it, then learnification, with its emphasis on generic skills and competences as learning outcomes, can in effect let teachers off the hook. It undermines their professionalism because the learnification process leaches away and reduces that crucial aspect of teachers' professional knowledge to do with what Zongyi Deng (in this special feature) calls 'content'. To repeat the frequently stated (but often misunderstood aphorism), teachers cannot just teach children, they must also teach them something. And, of course, that something needs to be worthwhile, in some way relevant to them and enjoyable (by which I understand, engaging).

So, the notion of teachers as 'facilitators of learning', emphasizing 'pedagogy' almost as an end in itself, is well intentioned and laudable, but on its own, not enough. Providing 'learners' with a variety of 'learning strategies' is arguably an abrogation of responsibility if this is not seen unequivocally as a means to an end. The contributors to this London Review of Education special feature are all therefore broadly with Biesta in his persuasive and provocative call to 'rediscover teaching' (2017). It is interesting to find that Hopkins (1996: 103) claims that, at the time he wrote the work quoted above (some twenty years ago), 'pedagogy' was not a term familiar in either schools or teacher education courses. Well, in the UK it most certainly is now, to the extent that pedagogy has become the quasi-technical language of teaching. This was in large part a result of the generic National Strategies that flowed from the UK New Labour governments from 1997. Thus, three-part lessons, thinking skills activities and frequent assessments of 'progress' enormously learnified the processes of education and, in some ways, distorted the relationship between teachers and students, and indeed the different relationship students and teachers have with the various subjects.

Most of the articles selected for this special feature are concerned with aspects of the blind spot I am beginning to allude to here - this being the realm of 'curriculum' as a conceptually distinctive category from 'pedagogy'. Just as pedagogy cannot, on its own, provide a wholly adequate language of teaching, so it is in the case of curriculum. Furthermore, one cannot replace the other. Thus, even though a teacher preparing to teach a lesson cannot afford to think too much about the conceptual distinction between curriculum and pedagogy - they merge into one highly practical set of operations - at some level, it is vital to acknowledge the distinction, which Young and Muller (2016) begin to explore in their collection Curriculum and the Specialization of Knowledge. In truth, they do not get far with pedagogy; indeed, it could be said that pedagogy is their blind spot. However, their writing, which explores the nature of 'powerful knowledge' and its role in reviving curriculum thinking (starting with the what and why of teaching, rather than the pedagogic focus on the how), has been influential in the articles that follow in this special feature. Furthermore, many explicitly reference 
their heuristic of 'three educational scenarios' first used by Young and Muller (2010) and again in Young et al. (2014) to introduce the radical and, in some ways, still exploratory notion of 'Future 3 ' curriculum thinking to school leaders. I return to this later.

Before doing so, we should take a substantial but necessary detour, as one stimulus for bringing together this special feature was the initiation of a new research group in the Department of Curriculum, Pedagogy and Assessment (CPA) at the UCL Institute of Education. This diverse group of subject-specialist teacher educators and scholars is known as the Subject Specialism Research Group (SSRG) and has the overarching aim 'to conduct, debate and promote research into subject-specialist teaching in both primary and secondary schools'.

The question that immediately arises is what counts as 'research into subject specialist teaching'? Referring yet again to Hopkins (1996: 102-3), we may find a clue, for he notes that 'outstanding teachers in OECD countries (have) command of "subject specific didactics" ... as well as a mastery of a repertoire of teaching models and strategies. It is in this domain that (the UK) lags behind [the] practice in other industrialised countries.' It is a shame that, apart from a brief, and possibly misleading definition - that subject didactics is about 'how best to teach maths, English, etc.' - the idea failed to receive serious consideration at the time. Indeed, possibly because of the rather toxic connotation of 'didactic' in the English language (teaching 'didactically' is not considered to be a virtue), the concept became subsumed under the new (for the UK) generic language of teaching: pedagogy. And yet, European research traditions in subject-specific didactics may hold considerable potential to frame research on teaching, knowledge and the curriculum, which are the main themes taken up in this special feature. It is significant to note that the SSRG has established links with similar groups in northern Europe such as ROSE (Research on Subject-specific Education) at Karlstad University in Sweden and HuSoEd (Research Community for Humanities and Social Sciences Education) at the University of Helsinki in Finland. Indeed, the articles included here feature authors from Sweden and the Netherlands. Furthermore, following his invitation to hold a seminar for the SSRG, this special feature presents an important contribution from Brian Hudson, one of the few UK academics to have explored didactics in depth (Hudson, 2016).

\section{Towards research-engaged teaching}

There is gathering momentum, both nationally and internationally, towards recognizing a research base that might inform teaching and teacher education (Beauchamp et al., 2013). Within this context, it is necessary to make a case for the kind of conceptual and practical research alluded to at the end of the previous section (and which this special feature attempts to illustrate).

We should note from the outset that, in the UK at least, the push for a more explicit, reliable evidence base for the teaching profession is part of a cultural and policy dynamic that offers, to say the least, some mixed messages (see Whitty, 2007). There is today perhaps a lack of clarity over the role of the expert in society at large and the place of 'evidence' in policymaking. Thus, Young and Muller have noted that:

in the present discursive climate of the 'knowledge economy', 'knowledge work' and 'expert occupations' there is simultaneously concern about the increase in the riskiness of professional judgement - the threat that codification and standardization poses to the autonomy and discretion of the traditional 'liberal' professional - and a residual suspicion about the 
probity and trustworthiness of all professions and professional judgement. (2016: 206-7)

But interestingly, they go on to add that:

the nature of professional knowledge has escaped scholarly notice and, when spoken about at all, is spoken about [only] in terms of ... what professionals can do with the knowledge. What the knowledge is that professionals have had to acquire to be experts has, by and large, eluded scholarly attention. (ibid.: 207; emphasis in original)

There is perhaps no other profession where this uncertainty concerning expertise bites more deeply than in teaching and teacher education, as we began to see in the previous section. It may be possible to dispute Young and Muller's claim - after all, the library shelves are heaving with conceptual and empirical research on curriculum, pedagogy and assessment, and other specialist fields such as technology or the study of inequalities in education (Scott and Scott, 2018). But it is surely possible to agree with the spirit of their assertion. Is there any consensus, even among those who might describe themselves as teacher educators, about the knowledge teachers need to acquire in order to become expert/professional teachers?

We are left with a paradox in which 'knowledge' has become the de rigueur qualifier of teaching, but one where the knowledge itself passes relatively unremarked. This holds true for an increasing number of self-proclaimed 'knowledge-led' schools. The official professional teaching standards in England (DfE, 2011) are understandably almost silent on knowledge itself, and instead focus on what the teacher can do or demonstrate. Despite a welcome nod towards teachers being able to 'demonstrate a critical understanding of developments in the subject and curriculum areas and promote the value of scholarship' (ibid.: 11), the standards tend to convey a somewhat static view of knowledge by asserting that teachers primarily need to have a 'secure' knowledge of the subject, enough, that is, to be able to correct students' 'misunderstandings'. As Lambert and Morgan (2010: 58, after Doerr et al., 2007) try to show, describing teachers as 'knowledge workers' requires a 'conceptual approach' to teaching geography that does not see 'geography' or 'teaching' (or, for that matter, 'education') as necessarily 'given' or secure.

In the landscape outlined in the above paragraphs, a number of distinctions are implied, such as the difference between knowledge of something (for example, geography, learning, etc.) and knowledge as something (for example, being a geography teacher), and the difference between theoretical and practical knowledge. This is not the place to explore this complexity in detail, but it is the place to ask, in the context of a research-engaged profession: what is the role of research for subject-specialist teaching in schools? To critically examine this question, we can take as a starting point Tony McAleavy's (2016) report for the Education Development Trust (EDT): Teaching as a Research-Engaged Profession: Problems and possibilities. This report offers a concise overview and synthesis of the wider and long-evolving discussion about evidence (see, for example, Hammersley, 2001; Goldacre, 2013) and research in education (for example, Stenhouse, 1981; Whitty, 2006; NFER, 2015). It makes a strong case for 'evidence-informed professionalism', the idea that underpins the 'research-engaged school'. A key distinction is made between teachers being participants in a profession that is evidence informed and teaching that is evidence based. The latter is heavily influenced by the government's insistence that randomized control trials (RCTs) imported from the world of scientific (especially medical) research 
provides 'the chance to make teaching a truly evidence-based profession' (DfE, 2013; my emphasis). However, it is possible to see that, even with the more relaxed notion of 'evidence-informed professionalism', we are still none the wiser about the knowledge itself - what knowledge teachers need to acquire in order to continue to develop as expert practitioners.

\section{Research engagement, reflective practice and curriculum enactment}

One reason for the rise of interest in evidence and teaching is the understandable instinct to improve the quality of teaching system-wide and to reduce the attainment gap for disadvantaged students. But before we come to this, another word or two on the broader context might be helpful, as there may be a sense in which the scramble for 'evidence' to inform teaching is a response to the conceptual thinness of many, if not most, initial teacher preparation pathways. The ubiquity of reflective practice, based on the globally influential Educating the Reflective Practitioner by Donald Schön (1990), has left something to be desired when it comes to clarifying the knowledge base of teaching.

Reflective practice as a methodology for professional preparation is attractive because it begins with the shortcomings of the technical-rational model of training which falsely assumed that a foundational disciplinary component can be taught, the principles of which can then be applied in real, practical contexts (in which day-to-day issues and events can also be accommodated). As Young and Muller remark, this led to:

the predicament that neophyte members of any profession experience facing their first client, patient or student; they don't know what to do and nothing they have learned in their university degree seems to be of any help. (2016: 212)

Schön's response was to promote what he called the 'epistemology of practice' which acknowledges the complexity and messiness of real world situations that do not lend themselves easily to technical 'problem-solving' approaches. This consists of what is essentially a pragmatic, judgement-based approach utilizing 'reflection in action', a thought process open to all human beings in any number of experiential settings. Although powerful, however, the limits of reflective practice are also now increasingly acknowledged (see, for example, Finlay, 2008). In the present context, it is perhaps its implicit anti-intellectualism that is the key issue, for it is not at all clear what reflective practice, on its own, brings to expert teaching. Reflective practice may be useful, necessary even, but in itself it does not identify the knowledge that should underpin what it means to be an expert/professional teacher. We therefore see a rising crescendo of concern that teachers' 'reflective judgements' should be based on evidence (as opposed to habit, custom or prejudice). For example, Impact, the journal of the Chartered College of Teaching (CCT), aims to connect 'research findings to classroom practice, with a focus on the interests and voices of teachers and educators. It supports the teaching community by promoting discussion around evidence within the classroom and enabling teachers to share and reflect on their own use of research' (https://chartered.college/journal). This is laudable, but of course leaves a number of questions hanging in the air. Whose evidence? What counts as evidence? How is evidence selected? How does it acquire warrant - what is its reliability and validity?

Thus, at the very beginning of the EDT report cited in the previous section, a cautious note is struck: 'It is probably both unrealistic and undesirable to think that 
teaching can be entirely based on findings from academic research' (McAleavy, 2016: 10). The report provides a clear critique of the limits of research that purports to show teachers 'what works' in the classroom. It points to the significance in teaching of context and the profound difficulties regarding the transferability of findings between settings and individual classrooms. A key distinction is made in this regard between research in education and medical research, citing Gert Biesta's 2007 article 'Why "what works" won't work'. Using evidence in teaching is yet more profoundly problematic: as Durham University's Evidence Centre for Education (DECE) has recently reported, one of the greatest challenges to using evidence in teaching is that:

much of the evidence is weak, and fundamental flaws in research are not uncommon. This is a serious problem if teaching practices and important policy decisions are made based on such flawed evidence. Lives may be damaged, and opportunities missed. (See, 2017: Abstract)

The EDT report is therefore correct in its contention that there exists very little, if any, high quality educational research in a form that offers teachers generally intelligible 'evidence' that may provide a blueprint to improve their practice. And yet, as the following two quotations illustrate (both from the CCT website), teachers are urged to use robust research evidence (the existence of which the DECE is sceptical about) and to think carefully about the evidence emerging from their own practices (a version of reflective practice):

teachers [need] access to a broad range of strategies, skills and knowledge which can be adapted and fine-tuned to meet widely-varying education contexts and pupil needs. This professional repertoire has to be informed by a body of rigorous, high quality research and evidence rather than based on taken-for-granted assumptions, routines and habits. (https://chartered.college/membership/knowledge-and-research)

A first step ... to make research evidence part of the way of doing things in your school is to ask questions. It was commonplace in some of the more research-engaged schools for conversations about dealing with issues in the classroom to include questions like 'what does the evidence show?' or 'what is your evidence for making that change?' (https://chartered. college/evidence-engagement)

For the sake of argument, we may accept the broad aim of the EDT and CCT - of a teaching profession that is mindful and aware of its contextual complexities and the limits of evidence-led practice, and yet seeks reasonably to show that professional decision-making is informed by a sound knowledge base. Nevertheless, from a subjectspecialist perspective, a residual problem remains, which is that teaching is portrayed as a technical, generic activity - leaving a relative silence about the quality of what is to be taught.

To raise this curriculum-oriented (rather than pedagogy-oriented) point takes us back to the question of moral purpose. This is related, particularly in secondary schools, to notions of the teacher's subject identity (Brooks, 2016) and takes us beyond a concept of the teacher as a highly skilled executive technician (Winch et al., 2013) to one that invests high levels of professional responsibility and autonomy in the teacher (see Orchard and Winch, 2015). In terms of preparing high quality subjectspecialist teachers, it is unhelpful if research engagement is associated only with school leadership priorities, possibly dominated by identifying techniques for raising 
attainment (at any cost). For example, with reference to the National Foundation for Educational Research's (NFER) 'Self Review Tool' (2015), the EDT report allows the focus of professional research engagement to drift to the unit of the school:

The tool invites schools [sic] to think about specific conditions for successful research engagement such as leadership commitment, staff participation levels and access to research-related resources ... based on a model of research engagement that places systematic enquiry at the heart of the school's approach to organisational development. (McAleavy, 2016: 34)

When 'schools' (as collectives of professionals) are asked to groupthink about research that might inform teaching, the tendency understandably is to focus on generic matters, providing evidence that can be applied across the school. Teachers' attention is drawn to general practices and principles of 'effective teaching' (such as lesson structure, use of data, techniques purporting to promote assessment for learning) and away from questions relating to the quality of what is taught and learned in this or that subject. Brian Hudson's article in this special feature contributes to redressing this blind spot by introducing the idea of the epistemic quality of what is taught and learned, helpfully relating this to Young's 'powerful knowledge'.

The CCT shows similar whole school drift. Thus, while acknowledging the importance of subject associations, the College claims to be:

opening up different pathways to research, including an online knowledge platform presenting evidence that goes beyond the everyday pragmatics of what works in the classroom (and what doesn't) to examine the core principles underpinning effective teaching.... (https://chartered.college/ membership/knowledge-and-research)

This explicitly asks us to think of teaching without considering what is to be taught, let alone its epistemic quality. Subject-specialist didactics (Hudson, 2016), on the other hand, requires teachers to keep in mind the relationship between the three elements of the 'didactic triangle': students, teachers and subject, which in the English context has been configured in a more familiar form, as 'curriculum making' (Lambert and Morgan, 2010; see also GeoCapabilities, www.geocapabilities.org).

To summarize, from the perspective of preparing high quality subject-specialist teachers, discussions about research engagement, though laudable, may be avoiding the elephant in the room and betray the blind spot identified in this article. This is the curriculum: the quality of its contents, its sequencing and its enactment are all curriculum enactment responsibilities that fall to teachers. A deeper appreciation of the professional knowledge required to be an effective subject-specialist teacher is essential if research engagement is to progress from the generic and the technical to offering a meaningful 'professional compass' (Brooks, 2016).

\section{Subject specialism, the curriculum, leadership and educational research}

If the curriculum - or more precisely curriculum making (Lambert and Biddulph, 2014) - is the elephant in the room, then it is interesting to note that Amanda Spielman, Ofsted's chief inspector, recently commented that the curriculum is one of the areas where there seems to be a blind spot in the way schools are routinely evaluated. She continues: 
Given the importance of the curriculum, it's surprising just how little attention is paid by our accountability system to exactly what it is pupils are learning in schools, particularly as we have been through a period of significant curriculum upheaval ...

The taught curriculum is in fact just one among 18 matters for consideration in reaching the leadership and management judgement, making it somewhat of a needle in a haystack. I believe that lack of focus has had very real consequences. (https://www.gov.uk/government/speeches/ amanda-spielmans-speech-at-the-ascl-annual-conference)

Looking to the future, Spielman's intentions for Ofsted are quite clear:

We will look at how schools are interpreting the national curriculum or using their academy freedoms to build new curricula of their own and what this means for children's school experience. We will look at what makes a really good curriculum. And we will also look at the problems, such as curriculum narrowing, and what we can do to tackle them. (Ibid.)

The new Ofsted focus on 'what it is pupils are learning in schools' - and the implication that there will be scrutiny of the quality of what is being taught - is a welcome rebalance away from the data-heavy approach to school evaluation that has taken hold in recent years. However, we should be aware that here too there is a risk of whole school drift, as noted in the previous section of this article, for when Spielman refers to building the curriculum, it seems that she is thinking at the level of a whole school curriculum design, rather than at the level of teachers' curriculum making. It is true that the breadth and balance of the whole school curriculum is a matter of utmost importance, but no more so than the quality of how the individual components of this curriculum are enacted in practice. It is at this level that issues of quality come into play: of content selection and sequencing, and the nature of engagement with the knowledge on the part of both students and teachers. The curriculum is about knowledge selection, but teachers need to work with this knowledge and ensure that students are meaningfully engaged with it. So, what are the implications of seeing teachers (and students) as 'knowledge workers' (Doerr et al., 2007 cited in Lambert and Morgan, 2010: 59)?

One of Michael Young's arguments is that everyday and immediately 'relevant' knowledge has gradually displaced specialized, disciplinary knowledge from the school curriculum. The tendency has been to integrate subjects, give greater priority to themes and cross-cutting dimensions in the school curriculum, and to reify 'learning to learn' and 'twenty-first century skills'. As we have seen earlier, Gert Biesta (2005, 2017) provocatively argues 'against learning' and for the need for teachers to grasp the significance of recognizing students as agents who should experience discomfort during the educational process. What unites such diverse critique is argument that encourages renewed focus on the need for teachers' deep appreciation of subject knowledge, its disciplinarity and its educational function. Following the logic of this position, we can see that curriculum leadership in schools must be distributed among teachers. In other words, responsibility for the curriculum as enacted must be owned by a far greater number of teachers than simply the senior leadership team - the prime reason for the caution noted earlier in this section about the possibility of whole school drift in Ofsted's renewed interest in the school curriculum.

In Knowledge and the Future School (Young et al., 2014), the authors begin to develop the notion of Future 3 curriculum thinking, based upon the socialrealist proposition of 'powerful' disciplinary knowledge. The 'three future scenarios' 
(Young and Muller, 2010) offer a potentially productive heuristic device that highlights some key distinctions in curriculum thinking. Thus, Future 3 distinguishes a rich, challenging curriculum of engagement with powerful knowledge from an outcomes or competences-led curriculum that appears to stress 'learning' as an end it itself, rather than a means to an end (Future 2). Future 3 is also distinguished from a traditional, factsbased curriculum of transmission (Future 1), in which curriculum content is predecided and given. Future 1 is often assumed to be the only possibility when knowledge is said to lead the curriculum and, under the influence of the US cultural theorist E.D. Hirsch (2007), this would appear to be the view of the UK's 2010 coalition government and subsequent Conservative governments. To use Hudson's terminology, the knowledge contents in the Future 1 scenario is of low epistemic quality in contrast to the aspirations of Future 3 thinking. The really problematic scenario is the learnified Future 2, but as Tim Oates (2018) points out, such differences between Futures 1 and 3, though important, may be quite subtle:

If Future 1 and Future 3 appear to have 'space' between them, then this could appear like the distance between the Earth and Moon. But if this is the analogy, then the distance between 1 and 3 is nothing compared to the difference between these at Future 2 - which in epistemological terms is in a galaxy far, far away. While Future 1 and Future 3 may require a short and intensive debate to resolve the practicalities of translation into legitimate curriculum policy, Future 2 was embedded in an entirely different and outdated conception of 'knowledge'. (2018: 159)

This means that although it may not be a legitimate interest of, say, politicians, to define precisely what is meant by 'powerful knowledge' (nor of the Future 3 curriculum thinking that it determines), it is exceedingly important for subject-specialist educationists to do so. I believe Oates underestimates what this implies by quite a distance. A 'short and intensive debate' may be sufficient for someone like him who is steeped in these issues. But it is because of the nuanced variance between Futures 1 and 3, together with the strong gravitational pull exerted by the familiarity of Future 1, that careful and regular thought needs to be given to the question of how to achieve the epistemic quality desired in Future 3 - and how to make this accessible to students from all backgrounds and circumstances. Future 3 encourages productive, rigorous and critical thought as developed in subject-specialist communities. In this special feature, articles from Bladh et al., Gericke et al. and Bouwmans and Béneker each provide a challenging exploration of the potential of such thinking. Platt's article offers yet another perspective on how Future 3 curriculum thinking might influence the development of textbooks. Though somewhat more hesitant about powerful knowledge and Future 3, Golding's article is also a thought-provoking discussion of teaching mathematics with a moral purpose. All these articles, whether their authors hail from the traditions of subject didactics or from the more pragmatic need to create teaching and learning materials, allude to the curriculum leadership responsibilities of teachers: that is, their need to 'pedagogize' the content matters, but without losing sight of who is being taught and the value of what is being taught.

It is clear that if we take the design and enactment of Future 3 curriculum thinking as an ideal, then not only does the significance of 'teacher-as-curriculum-maker' begin to take shape, but a substantial possible research agenda also emerges. For example, in what ways is disciplinary knowledge recontextualized to become a meaningful school subject? How might this process vary between subjects? What might powerful disciplinary knowledge look like in different subjects? How do we maximize 'epistemic 
access' to specialized knowledge, perhaps leading to 'epistemic ascent' (Winch, 2013)? What are the implications for pedagogy if we aspire to teach a Future 3 curriculum? In what ways does a Future 3 curriculum prepare pupils effectively for examinations? Do examinations themselves need to change? What is the role of 'textbooks' (in the broadest sense of the term - see Oates, 2014) and other learning resources in a Future 3 curriculum? There are many others areas that might be examined. The relationship that any specialist teacher, not to mention those with official subject leadership responsibilities, has with such a research agenda is a crucial aspect to explore.

\section{Conclusion: 'Research engagement' for subject teachers}

To return to our earlier discussion of teachers' engagement in research, it is perhaps clear that again we have to reconsider the nature of what we mean by 'research', and in what way (or whether) the notion of evidence - particularly that propagated by agencies such as the Education Endowment Foundation (EEF) - really works in support of forms of high quality teaching implied in the preceding discussion. Thus, in their laudable attempt to promote the agency and autonomy of teaching professionals, the CCT states that:

it is also vital that the teaching profession claims ownership of translating research findings into practice rather than allowing those outside the classroom to do so on their behalf. (https://chartered.college/membership/ knowledge-and-research)

This statement begs the question of whether those 'outside' classrooms are even able to translate research into practice. Wilfred Carr (2007) has pursued this question in considerable depth and points out the inevitable failure of educational research, conceived of as a 'species of social science', to undertake research on or about education, at the same time conducted to meet criteria of practical relevance in the classroom. The ready solution to the futility of squaring this particular circle has been to focus on classroom practitioners themselves and to encourage classroom teachers to conduct research - an expression perhaps of what Geoff Whitty (1985) originally referred to as 'naïve possibilitarianism', albeit in a different context. We have already hinted at how unhelpful it is to expect the role of the teacher to expand to become a researcher too - bearing in mind, of course, that there are always exceptions that serve to prove the rule. To heap active research onto teachers is an unreasonable and unnecessary expectation, and a distraction from teachers' core professional responsibility for curriculum making. The latter requires teachers to be engaged with particular kinds of research and scholarship that can assist them in what we referred to earlier as their moral purpose.

One of the issues that Carr points to is that the form of research appropriate to educational practice should be understood not as a branch of social science but 'as a species of praxis'. This describes teaching as '... a form of ethical action in which, and through which, a commitment to some educationally worthwhile "end" is given practical expression' (2007: 276; my emphasis). In this context Carr seeks to reconfigure educational research as a 'practical science'. This would:

be a form of research that no longer produces social scientific knowledge 'on' or 'about' education but instead develops the kind of self-knowledge that enables practitioners to identify the unquestioned assumptions and irrational beliefs sustaining their practice and, by so doing, enables them to evaluate their practice on the basis of a coherent and clearly articulated 
educational point of view. In this sense, it is a form of educational research that allows practitioners to reconstruct their practice as educational practice in a rational and reflective way. (Ibid.: 282; emphasis in original)

Perhaps the key point here is that educational practitioners need a clear conception of the educational purposes that guide or shape their sound classroom judgements. A component of expert, professional 'teacher knowledge' therefore concerns the nature of what they are teaching and how this contributes to some educationally worthwhile end. It may be difficult to demonstrate the practical relevance of research 'on' or 'about' education that does not speak to this context-specific, ethical dimension of teaching.

To put this another way, the curriculum matters and teachers need to understand - and accept responsibility for - their part in curriculum leadership. The subject curriculum is concerned with the central questions:

- Who are the students?

(What is their prior experience and knowledge? What are their aspirations?)

- Why teach this subject? (How does it justify curriculum space? What is its educational value?)

- What should be taught?

(On what basis do we select what to teach? How is this sequenced?)

- How do we best teach this subject?

(What pedagogic approaches are suited to serving the purposes identified above?)

It perhaps goes without saying that the overarching frame for these questions is Future 3 curriculum thinking, as outlined earlier in this article. The significance of the questions might explain why much that is published in the scholarly sub-fields of subject specialism in education tends to be conceptual in nature. The dearth of large-scale empirical research in many subject domains such as geography education research, which is often thought to be a sign of weakness (Lambert, 2015), may therefore be reinterpreted as an intention to be something more like a 'practical science' (as articulated by Carr above). If geography educationists (or other subject specialists) aspire to provide a high quality, knowledge-led Future 3 curriculum, then teachers have to make it happen. Teachers cannot 'sub-contract' the curriculum making. Furthermore, teachers as curriculum makers probably need to be engaged in some way with the 'disciplinarity' of their specialist subject (see Knight and Benson, 2013) and with the related conceptual and scholarly debates that exist outside their own school contexts.

In summary, there is a need to prioritize subject-specialist teacher development that focuses on the quality of the curriculum as experienced by children and young people. This requires teachers to engage professionally with conceptual debates about their subject and its contribution to the curriculum. They need the intellectual as well as the practical tools to enable them to take responsibility for curriculum leadership, manifest through the enactment of Future 3 curriculum thinking.

In 2015, the EEF - whose mission it is to 'fund the development and evaluation of cost-effective and scalable projects that seek to improve the educational attainment of children and young people from disadvantaged backgrounds' (educationendowmentfoundation.org.uk) - explicitly encouraged applications to fund projects that had a subject focus. This was welcomed by many as a gesture to rebalance the range of projects funded by EEF away from whole school, generic interventions that now make up the bulk of the profile in their emerging 'Teaching and Learning Toolkit'. However, my understanding is that the call for such applications 
met with a limited response. Apart from research in mathematics and science, the call for subject-focused research appears to have been withdrawn. Though regrettable, this eventuality is not surprising. For one thing, the research-active infrastructure in many research sub-fields such as geography is fragile in higher education, having been undermined by the deinstitutionalization of teacher education in recent years. In addition, the particular nature of the research supported by the EEF is problematic for subject-specialists, especially in schools. For example, the EEF requires 'evidence of promise' that specific interventions actually 'work' and can be 'scaled up'. This is, as I have argued, inappropriate.

We should not allow the communities of scholarship in subject specific domains in education to be diverted from the enduring and significant task of deepening and extending professional repertoires of thought and practice to do with teachers' interpretation and enactment of the curriculum. This includes conceptual work focused on the development of subject-specialist teaching and its educational significance for students.

\section{Acknowledgements}

David Lambert would like to thank members of the Geography Education Research Collective (www.gereco.org) for commenting critically and constructively on earlier versions of this article. Any deficiencies that remain are, of course, all mine.

\section{Notes on the contributor}

David Lambert is Professor of Geography Education at UCL Institute of Education. A former secondary schoolteacher and teacher educator, he also enjoyed a stint as Chief Executive of the Geographical Association (2002-12). Recent books include Learning to Teach Geography in the Secondary School (with Mary Biddulph and David Balderstone; Routledge, 2015, 3rd ed.) and Debates in Geography Education (with Mark Jones; Routledge, 2017, 2nd ed.). He chairs the Editorial Collective of the Geography Association's leading journal Geography and serves as Associate Editor of International Research in Geographical and Environmental Education.

\section{Note}

${ }^{1}$ www.geocapabilities.org: This EU(Comenius)-funded project was led by UCL Institute of Education between 2013 and 2017 with partners in Europe and the United States (www.geocapabilities.org/ about/partners/).

\section{References}

Beauchamp, G., Clarke, L., Hulme, M. and Murray, J. (2013) Research and Teacher Education: The BERA-RSA Inquiry: Policy and practice within the United Kingdom. London: British Educational Research Association.

Bernstein, B. (2000) Pedagogy, Symbolic Control and Identity: Theory, research, critique. Rev. ed. Lanham, MD: Rowman and Littlefield.

Biesta, G. (2005) 'Against learning: Reclaiming a language for education in an age of learning'. Nordisk Pedagogik, 25, 54-66.

Biesta, G. (2007) 'Why "what works" won't work: Evidence-based practice and the democratic deficit in educational research'. Educational Theory, 57 (1), 1-22.

Biesta, G.J.J. (2017) The Rediscovery of Teaching. London: Routledge.

Brooks, C. (2016) Teacher Subject Identity in Professional Practice: Teaching with a professional compass. London: Routledge. 
Carr, W. (2007) 'Educational research as a practical science'. International Journal of Research and Method in Education, 30 (3), 271-86.

Chartered College of Teaching (ССT) Impact. Online. https://chartered.college/journal (accessed 6 August 2018).

Department for Education (DfE) (2011) Teachers' Standards: Guidance for school leaders, school staff and governing bodies. London: Department for Education. Online. https://assets. publishing.service.gov.uk/government/uploads/system/uploads/attachment_data/file/665520/ Teachers_Standards.pdf (accessed 30 July 2018).

Department for Education (DfE) (2013) 'Building evidence into education'. News story, 14 March. Online. www.gov.uk/government/news/building-evidence-into-education (accessed 31 July 2018).

Doerr, A.M. Ruffus, Chambers, E.A. and Keefer, M.W. (2007) 'The changing role of knowledge in education'. Education, Knowledge and Economy, 1 (3), 279-300.

Finlay, L. (2008) Reflecting on 'Reflective Practice' (PBPL Paper 52). Open University. Online. www.open.ac.uk/opencetl/sites/www.open.ac.uk.opencetl/files/files/ecms/web-content/Finlay\%282008\%29-Reflecting-on-reflective-practice-PBPL-paper-52.pdf (accessed 1 August 2018).

Fullan, M. (1993) Change Forces: Probing the depths of educational reform. London: Falmer Press.

GeoCapabilities (n.d.) 'Training materials: Module 2 - Curriculum making by teachers'. Online. www.geocapabilities.org/training-materials/module-2-curriculum-making-by-teachers/aims/ (accessed 1 August 2018).

Goldacre, B. (2013) Building Evidence into Education. London: Department for Education. Online. http://media.education.gov.uk/assets/files/pdf/b/ben\%20goldacre\%20paper.pdf (accessed 1 August 2018).

Hammersley, M. (2001) 'Some questions about evidence-based practice in education'. Paper presented at the British Educational Research Association (BERA) Annual Conference, University of Leeds, 13-15 September 2001. Online. www.leeds.ac.uk/educol/documents/00001819.htm (accessed 1 August 2018).

Hirsch, E.D. (2007) The Knowledge Deficit: Closing the shocking education gap for American children. Boston: Houghton Mifflin.

Hopkins, D. (1996) '"New rules" for the radical reform of teacher education'. In Hudson, A. and Lambert, D. (eds) Exploring Futures in Initial Teacher Education. London: Institute of Education.

Hudson, B. (2016) 'Didactics'. In Wyse, D., Hayward, L. and Pandya, J. (eds) The SAGE Handbook of Curriculum, Pedagogy and Assessment. London: SAGE Publications, 107-24.

Knight, O. and Benson, D. (2013) Creating Outstanding Classrooms: A whole-school approach. London: Routledge.

Lambert, D. (2015) 'Research in geography education'. In Butt, G. (ed.) MasterClass in Geography Education: Transforming teaching and learning. London: Bloomsbury Academic, 15-30.

Lambert, D. and Biddulph, M. (2014) 'The dialogic space offered by curriculum making in the process of learning to teach, and the creation of a progressive knowledge led curriculum'. Asia Pacific Journal of Teacher Education, 43 (3), 210-24.

Lambert, D. and Morgan, J. (2010) Teaching Geography 11-18: A conceptual approach. Maidenhead: Open University Press.

McAleavy, T. (2016) Teaching as a Research-Engaged Profession: Problems and possibilities. Reading: Education Development Trust.

NFER (National Foundation for Educational Research) (2015) Self-Review Tool for research engagement in schools and other education providers. National Foundation for Educational Research. Online. https://apps.nfer.ac.uk/SRT/Index.html (accessed 29 August 2018).

Oates, T. (2014) Why Textbooks Count: A policy paper. Cambridge: Cambridge Assessment. Online. www.cambridgeassessment.org.uk/Images/181744-why-textbooks-count-tim-oates.pdf (accessed 1 August 2018).

Oates, T. (2018) 'Powerful knowledge - moving us all forwards or backwards?'. In Guile, D., Lambert, D. and Reiss, M.J. (eds) Sociology, Curriculum Studies and Professional Knowledge: New perspectives on the work of Michael Young. London: Routledge, 157-68.

Orchard, J. and Winch, C. (2015) 'What training do teachers need? Why theory is necessary to good teaching'. Impact: Philosophical Perspectives on Education Policy, 22, 1-43.

Schön, D.A. (1990) Educating the Reflective Practitioner: Toward a new design for teaching and learning in the professions. San Francisco: Jossey-Bass.

Scott, D. and Scott, B. (2018) Equalities and Inequalities in the English Education System. London: Trentham Books. 
See, B.H. (2017) 'Evaluating the evidence in evidence-based policy and practice: Examples from systematic reviews of literature'. Research In Education, 1-25. Online. http://journals.sagepub. com/doi/pdf/10.1177/0034523717741915 (accessed 2 August 2018).

Stenhouse, L. (1981) 'What counts as research?'. British Journal of Educational Studies, 29 (2), 103-14.

Uhlenwinkel, A., Béneker, T., Bladh, G., Tani, S. and Lambert, D. (2017) 'GeoCapabilities and curriculum leadership: Balancing the priorities of aim-based and knowledge-led curriculum thinking in schools'. International Research in Geographical and Environmental Education, 26 (4), 327-41.

White, J. (2018) 'The weakness of "powerful knowledge"'. London Review of Education, $16(2), 325-35$.

Whitty, G. (1985) Sociology and School Knowledge: Curriculum theory, research and politics. London: Methuen.

Whitty, G. (2006) 'Education(al) research and education policy making: Is conflict inevitable?'. British Educational Research Journal, 32 (2), 159-76.

Whitty, G. (2007) 'Education research under New Labour: Some lessons'. Keynote address presented at the Australian Association for Research in Education (AARE) Annual Conference, Fremantle, WA, 25-29 November 2007. Online. www.aare.edu.au/data/publications/2007/ whi07644.pdf (accessed 2 August 2018).

Winch, C. (2013) 'Curriculum design and epistemic ascent'. Journal of Philosophy of Education, 47 (1), 128-46.

Winch, C., Oancea, A. and Orchard, J. (2013) The Contribution of Educational Research to Teachers' Professional Learning: Philosophical understandings (Research and Teacher Education: The BERA-RSA Inquiry). London: British Educational Research Association. Online. www.bera. ac.uk/wp-content/uploads/2014/02/BERA-Paper-3-Philosophical-reflections.pdf (accessed 2 August 2018).

Young, M. (2018) 'A knowledge-led curriculum: Pitfalls and possibilities'. IMPACT, September.

Young, M., Lambert, D., Roberts, C. and Roberts, M. (2014) Knowledge and the Future School: Curriculum and social justice. London: Bloomsbury Academic.

Young, M. and Muller, J. (2010) 'Three educational scenarios for the future: Lessons from the sociology of knowledge'. European Journal of Education, 45 (1), 11-27.

Young, M. and Muller, J. (2016) Curriculum and the Specialization of Knowledge: Studies in the sociology of education. London: Routledge. 